\title{
Spatial patterns of evapotranspiration distribution in palm oil plantation
}

\author{
YAZID ISMI INTARA $^{1, \bullet}$, ABIMANYU DIPO NUSANTARA ${ }^{1}$, SUPANJANI ${ }^{1}$, ZULBAHRUM CANIAGO $^{2}$, \\ RISKA EKAWITA ${ }^{2}$ \\ ${ }^{1}$ Faculty of Agriculture, Universitas Bengkulu. Jl. WR. Supratman, Kandang Limun, Bengkulu 38371. Bengkulu, Indonesia. \\ Tel.: +62-736-21170; Fax.: +62-736-21290, `email: izmi_6@yahoo.com \\ ${ }^{2}$ Faculty of Mathematic and Natural Sciences, Universitas Bengkulu. Jl. WR. Supratman, Kandang Limun, Bengkulu 38371. Bengkulu, Indonesia
}

Manuscript received: 9 December 2017. Revision accepted: 2 December 2018.

\begin{abstract}
Intara YI, Nusantara AD, Supanjani, Caniago Z, Ekawita R. 2019. Spatial patterns of evapotranspiration distribution in palm oil plantation. Nusantara Bioscience 11: 1-7. Evapotranspiration can directly calculate by some climatic factors which are processed in the form of simulation modeling of two-dimensional evaporation distribution on specified coordinates. This research had been conducted in palm oil plantation PT. Bio Nusantara Bengkulu, Indonesia. The sampling location covered some areas named as TM2, TM22, Palm oil-Field, Palm oil-Residential Area and Palm oil-Secondary Forest. The TM2 and TM22 were a location of palm oil plantation used for 2 and 22 years planting respectively. The three remaining locations dedicated to areas of which mix TM22 with soccer Field, Residential Area and Secondary Forest. The results showed that in palm oil plantation TM 2 which consisted of herbaceous plants and bushes produced more water vapor. At palm oil plantation TM 22 which had fully developed canopy or the entire soil area had been covered by canopy, so only transpiration occurred at this site, less water vapor was produced. This is due to the temperature condition is inversely proportional to the relative humidity. As a comparison of a palm oil plantation evapotranspiration measurement result, indicated on area of football field where only has grass in the field, with low intensity of light, wind, and humidity, affected directly to high amount of evapotranspiration, therefore, more water vapor produced. The measurement result of palm oil plantation nearby residential area showed that the area which consisted of herbaceous plants and bushes, also zinc-roofed residential with the intensity of light and wind directly hit the area, produced less water vapor. Moreover, the condition at the border area between TM 22 and the palm oil secondary forest contained mixed plantation. The measurement result showed that the palm oil secondary forest had the same height of canopy and almost had equal humidity (>76\%), but secondary forest plants had more dense plantation density which produced less water vapor.
\end{abstract}

Keywords: Canopy, evapotranspiration, humidity, palm oil, spatial distribution

\section{INTRODUCTION}

Water for plants serves as major-substance in the process of photosynthesis and hydrolysis, as well as in maintaining turgor cell (Lee 1988). Water shortage would be facing plants in situation culminating in the disruption of their growth. The level of water used by plants was varied, one of the plants that require large amounts of water is palm oil (Elaeis guineensis Jack) (Röll et al. 2015). In terrestrial environment, plants absorb water from the soil by their root system, and subsequently transported to the shoot through vascular conduit and finally released by leaves in form of water vapor, the phenomena known as transpiration. The term Evapotranspiration intends to the process of water loss from a land use through evaporation from the soil surface and transpiration from plant surfaces.

Evaporation greatly depends on the availability of thermal energy. Sunlight is the dominant source of energy which functions as a limiting factor of the temperature so that if the solar irradiance is high as in the tropical area, then the evaporation will be relatively high as well. As the temperature would directly be linked to the vapor pressure gradient (Bakoumé et al. 2013), its value is inversely proportional to the relative humidity. While the temperature in particular area increases, then the relative humidity decreases. Air humidity is a factor that affects evaporation as humidity describes water vapor present in the air that affects the air capacity to absorb water vapor. If the air humidity is high, then the evaporation will be low. Furthermore, wind speed is also an important factor affecting evaporation. Wind has a significance impact on the movement or transfer of water vapor. If turbulence (wind speed) is high on above the surface, a layer of saturated air transferred by the wind will be more numerous so that evaporation increases (Rakecha dan Singh 2009).

Differences in transpiration resistance, plant height, canopy closure, and the roots will cause the difference in the magnitude of evapotranspiration (Courault et al. 2003). The rate of water loss (evapotranspiration) of palm oil plantation is quite high due to the evaporation area of the leaves are relatively vast. Evapotranspiration is not only used in the estimation of groundwater availability, but it is also an indicator of plant water requirements (Röll et al. 2015; Meijid et al. 2017).

Evaporation of groundwater and transpiration by plants are main contributors to the formation of air humidity (Kizer and Elliot 1991). When the number of water 
molecules in water vapor increases for a certain time until the content in the air equals the amount of water due to evaporation, then saturated state of the air occurs. The vapor pressure when in a state of saturation is called saturated vapor pressure. The vapor pressure of saturated liquids increases along with temperature. The partial pressure is the pressure that will be given if each gas filled the entire volume. The ratio of the partial pressure to the saturated vapor pressure at a given temperature is called relative humidity (Giancoli 1998).

Evapotranspiration is a chain of hydrological cycle that occurs in two ways, namely potential evapotranspiration and actual evapotranspiration. The actual value of evapotranspiration represents the value of water demand that must be given to the plant, or is the basis for the fulfillment of plant water requirements in the field (Sterling et al. 2012).

Potential evapotranspiration occurs when a considerable amount of groundwater are presented, whereas actual evapotranspiration occurs when groundwater conditions are inadequate (Usman, 2004). Evapotranspiration change is greatly affected by the regional climate that plays an important role in the calculation of groundwater availability (Corley 1996; Bakoumé et al. 2013). Evapotranspiration calculation can be done by several methods. One method that is considered ideal in the estimation of spatial evapotranspiration is the Penman method (Kizer and Elliot 1991, Dufrene et al. 1992; Mujiharjo, 2002; Usman, 2004). Evapotranspiration calculation (JPS 1991; Wilson et al. 2012; Arshad, 2014) is an approach to energy availability and mass equilibrium combination.

\section{MATERIALS AND METHODS}

\section{Study area}

The study was conducted by measuring the elements of regional climate (solar radiation, air temperature, air humidity, and wind speed) in palm oil plantation PT. Bio Nusantara, District of Bengkulu Tengah, Bengkulu Province, Indonesia. The sampling location covered some areas named as TM2, TM22, Palm oil-Field, Palm oilResidential Area and Palm oil-Secondary Forest. The TM2 and TM22 were a location of palm oil plantation used for 2 and 22 years planting respectively. The three remaining locations dedicated to areas of which mix TM22 with soccer Field, Residential Area and Secondary Forest.

Coordinates of the study sites as follows: (i) TM 2: $3^{\circ} 36^{\prime} 45.84$ " south latitude and 102 $17^{\prime} 24.08^{\prime \prime}$ east longitude, (ii) TM 22: $3^{\circ} 38^{\prime} 3.28^{\prime \prime}$ south latitude and $102^{\circ} 15^{\prime} 10.96^{\prime}$ east longitude, (iii) Palm oil-Field: $3^{\circ} 38^{\prime} 21.38^{\prime \prime}$ south latitude and $102^{\circ} 15^{\prime} 51.87^{\prime \prime}$ east longitude, (iv) Palm oil-Residential Area: 3'36'53.58" south latitude and 102017'18.77' east longitude, (v) Palm oil-Secondary Forest: 3'36'23.93" south latitude and $102^{\circ} 15^{\prime} 33.15^{\prime \prime}$ east longitude.

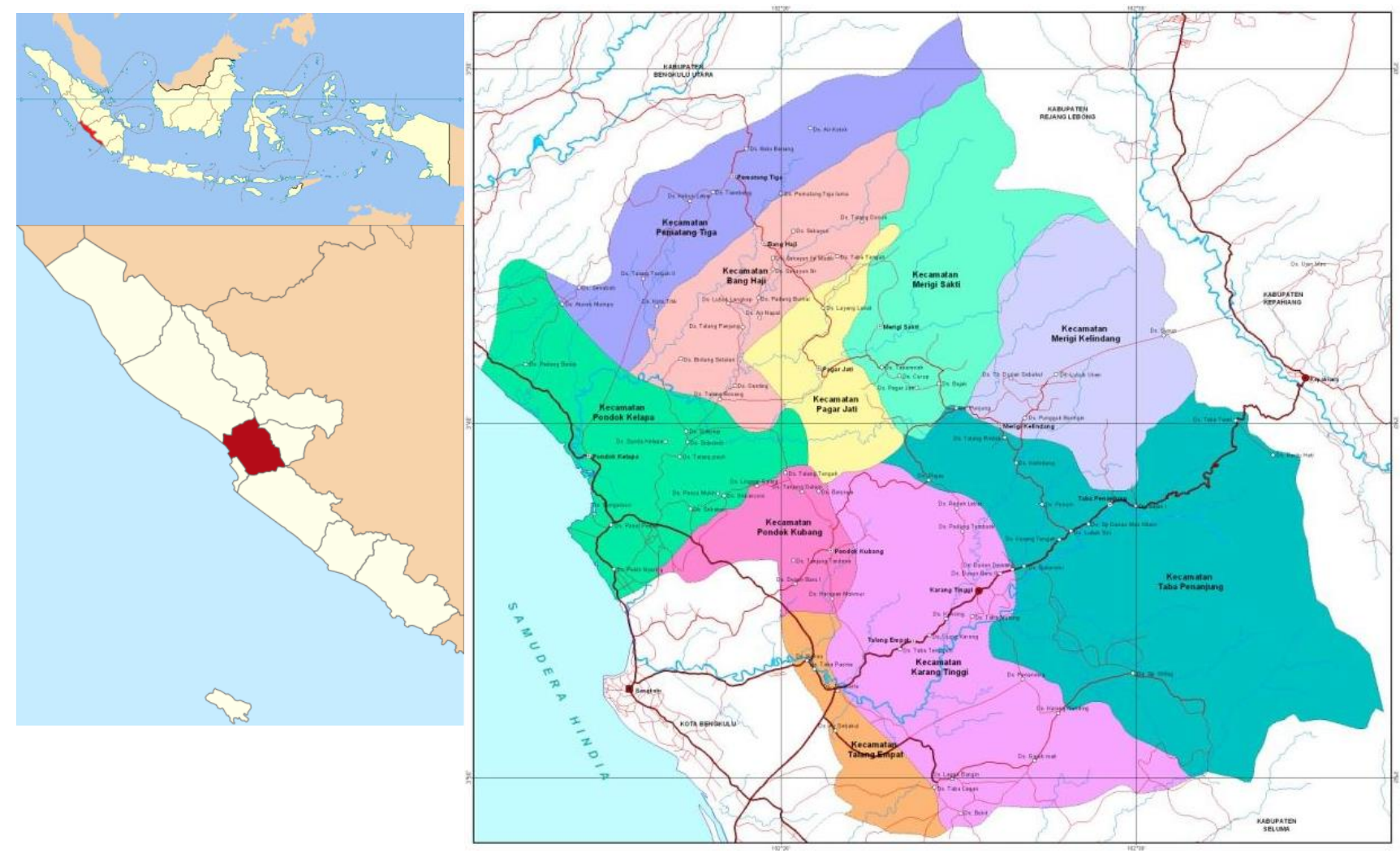

Figure 1. Location of Bengkulu Tengah District at Bengkulu Province of Indonesia 


\section{Procedures}

All measurement was conducted on regional climate elements including air humidity by humidity meter HT3006A, wind speed by anemometer, light intensity by Luxmeter, and coordinate point determined by Global Positioning System (GPS) Garmin brand GPSMAP 64s, drone (phantom 3 standards). To obtain accurate data, all measurements were accommodated at the same time around 07.30-17.30, and the weather throughout the region is constantly sunny. In addition, some standard data were used: sun exposure period (n) (which obtained from the Meteorological Center), the temperature related factors, saturated vapor pressure at average temperature, average duration of solar irradiance and shortwave radiation probability that meets the outer layer of the atmosphere.

Regional climate elements (solar radiation, air temperature, air humidity, and wind speed) were measured in several observation points. The number of observation points in each region was varied depending on the field conditions. The measurement interval on the $\mathrm{x}$-axis was 20 meter. The measurement range on the $\mathrm{x}$-axis was 120 meter. The number of measurement point on the $\mathrm{x}$-axis was 7 points. The measurement interval on the y-axis was 20 meter. The measurement range on the y-axis was 120 meter. The number of measurement point on the y-axis was 7 points.

Evapotranspiration was estimated as an approach to energy availability and mass equilibrium combination (Penman 1948; JPS 1991) which expressed in the form of:

$$
E T=w\left(0.75 R_{s}-R_{n 1}\right)+(1-w) f(u)\left(e_{a}-e_{d}\right)
$$

Where, ET is evapotranspiration magnitude $\left(\mathrm{mm} \mathrm{day}^{-1}\right)$, $\mathrm{w}$; the temperature related factors, $\mathrm{R}_{\mathrm{n} 1}$; long wavelength net radiation $\left(\mathrm{mm} \mathrm{day}^{-1}\right)$, Rs; shortwave radiation $\left(\mathrm{mm} \mathrm{day}^{-1}\right)$, $\mathrm{e}_{\mathrm{d}}$; function of wind speed at a height of 2 meters $\left(\mathrm{m} \mathrm{s}^{-1}\right)$ and $e_{a}$; the difference of saturated vapor pressure with the actual saturated vapor pressure (Sirrgudsson et.al, 2008).

Mavi and Tupper (1984) stated that evapotranspiration was empirically correlated with weather factors such as air temperature, solar radiation, wind, air humidity or a combination of these factors. In addition, according to Rakecha and Singh (2009), air pressure also contributed to the rate of evapotranspiration.

The total radiation in the Penman calculation method is always estimated with the assumption that the surface temperature and the air are the same (Usman, 2004). Shortwave radiation in evaporation units (Rs) is calculated by the equation:

$$
R_{s}=\left(0.25+0.54 \frac{n}{N}\right) R_{a}
$$

Whereas, $\mathrm{n}$ is sun exposure period (hour), $\mathrm{N}$ is the possibility of the average duration of sun exposure latitudelongitude based on the location of the area, and $\mathrm{Ra}$ is shortwave radiation that meets the outer layer of the atmosphere influenced by the location of the latitude of the area. Long wavelength net radiation is calculated by the equation:

$$
\begin{aligned}
& R_{n 1}=f(t) \times f(e d) \times f\left(\frac{n}{N}\right) \\
& f(e d)=0.34-0.44 \times \sqrt{e d} \\
& f \frac{n}{N}=0.1+0.9 \frac{n}{N}
\end{aligned}
$$

Whereas, $f(t)$ function of temperature, $f(e d)$ function of vapor pressure and $f(n / N)$ function of brightness. Function of wind speed at the height of $2 \mathrm{mf}(\mathrm{u})$ is calculated by the equation:

$$
f(u)=0.35\left(1+0.526 U_{2}\right.
$$

Whereas, wind speed in the height of $2 \mathrm{~m}\left(\mathrm{~m} \mathrm{~s}^{-1}\right)$. Actual vapor pressure ed is calculated by the equation:

$$
\mathrm{ed}=\mathrm{e}_{\mathrm{a}} \times \mathrm{Rh}
$$

Whereas, $e_{a}$ is saturated vapor pressure in average temperature and $\mathrm{Rh}$ is air humidity $(\%)$.

\section{Data analysis}

Evapotranspiration is the process of water loss through evaporation of soil surface and transpiration of plants. There are several ways to determine evapotranspiration, one of them is by directly calculating some climatic factors which are processed in the form of simulation modeling of two-dimensional evaporation distribution on specified coordinates. Evapotranspiration distribution modeling can be done through the determination of numerical solutions. The evapotranspiration distribution model can be found by direct measurement of several points but it can not be applied for over the whole space. The Lagrange polynomial interpolation method is very effective to predict the unmeasured data points between the measured data points making it possible to model spatial evapotranspiration distribution.

The measurement data were processed and calculated to obtain the evapotranspiration magnitude at the observation points which has been specified in initial survey. The calculation results are then modeled using Lagrange polynomial interpolation by using program that has been designed in MATLAB software. Furthermore, the model of the spatial distribution of evapotranspiration was analyzed to determine the potential water outflow in each area. 


\section{RESULTS AND DISCUSSION}

\section{Evapotranspiration distribution in palm oil TM2 and TM22}

The evapotranspiration measurement on plantation TM2 is shown in Figure 2. The results of the measurements showed that the minimum evapotranspiration distribution was $5 \mathrm{~mm} /$ day located at the position $\mathrm{x}=16$ and $\mathrm{y}=20$. Palm oil plantation TM2 still had undeveloped canopy, or there was exposed soil area that was not covered with canopy and there was dirt road at that site so that less moisture was produced.

The results show that the maximum evapotranspiration distribution was $7 \mathrm{~mm} \mathrm{day}^{-1}$ located at the position $\mathrm{x}=60$ dan $y=50$. In addition to palm oil plant TM 2, there were herbaceous plants and bushes which producing more water vapor. Based on the model, evapotranspiration distribution at TM 2 site in PT. Bio Nusantara was uneven and had magnitude around 5-7 $\mathrm{mm} \mathrm{day}^{-1}$.

The results of the evapotranspiration distribution measurements in plantation TM22 are shown in Figure 3. Minimum evapotranspiration was $5 \mathrm{~mm} \mathrm{day}^{-1}$ located in position $\mathrm{x}=15$ and $\mathrm{y}=35$. Palm oil plantation TM 22 already had a fully developed canopy or the entire soil was covered by canopy therefore only transpiration occurred in plantation TM 22 so resulted in less water vapor. Maximum evapotranspiration was $7 \mathrm{~mm}$ day $^{-1}$ located at the position $\mathrm{x}=120$ and $\mathrm{y}=70$. There were plants which didn't grow simultaneously due to humidity. Some plants didn't grow simultaneously due to moisture, air movement and light intensity which ramps up the magnitude of evapotranspiration. Based on the model, evapotranspiration distribution in plantation TM 22 in PT. Bio Nusantara was fairly even and had value around 5-7 $\mathrm{mm} \mathrm{day}^{-1}$ (see Figure 3).

The temperature is inversely proportional to the relative humidity. If the temperature increases, then the relative humidity decreases. Air humidity is a factor that affects evaporation because humidity describes water vapor contained by air that affects the air's capacity to absorb water vapor. If the air humidity is high, then the evaporation will decrease.

This condition occurred when measuring the evapotranspiration distribution model in palm oil plantation TM 22. Humidity beneath canopy of TM22 was quite high around $>76 \%$. Therefore, the result of the evapotranspiration distribution model was low. In condition that all area was covered with canopy, only transpiration occurred or evaporation could be ignored.

\section{Comparison Between TM22 with other Environment}

The results of the evapotranspiration distribution measurements in Palm oil-Field are shown in Figure 4. The image shows that the minimum evapotranspiration was 5 $\mathrm{mm}$ day $^{-1}$, located in position $\mathrm{x}=100$ and $\mathrm{y}=0$. Palm oilfield was divided into two conditions: a palm oil plantation TM 22 and a football field. The minimum evapotranspiration magnitude was shown in the plantation TM 22 due to its higher humidity (> 80\%) so that less water vapor was produced. Maximum evapotranspiration was $7 \mathrm{~mm} \mathrm{day}^{-1}$ located in position $\mathrm{x}=10$ and $\mathrm{y}=100$. The location of a football field, where only grass on the field with low intensity of light and wind directly hit the area, affected high evapotranspiration magnitude producing more water vapor. Based on the model, the evapotranspiration at the Palm oil-Field location in the PT Bio Nusantara palm oil plantation was unevenly distributed, divided into two conditions and approximately 5-7.5 $\mathrm{mm} \mathrm{day}^{-1}$.

According to Allen et al. (1998), evapotranspiration has a unit of millimeters $(\mathrm{mm})$ per unit of time. If the plants are still small, the water loss tends to be larger from the surface of the ground. Whereas, if plant canopy has covered the ground, transpiration becomes the main process occurred. When palm oil plant is small, evapotranspiration is more dominant than evaporation of soil surface because only a small part of the soil surface is covered by palm oil canopy. Whereas after palm oil is grown, the plant canopy almost covers all parts of the soil surface so that evapotranspiration is more dominant than the evaporation of the surface of palm oil (Röll et al.2015).

Measurements of other evapotranspiration distributions at the Palm oil-Residential area are indicated in Figure 5. The location was a site with heterogeneous residential area condition, located at the site of the palm oil plantation TM4 PT. Bio Nusantara. The results showed that the minimum evapotranspiration had a value of $5.5 \mathrm{~mm} /$ day located at the position $\mathrm{x}=70$ and $\mathrm{y}=0$ also $\mathrm{x}=60$ and $\mathrm{y}=100$. The area which consisted of herbaceous plants and bushes, also zinc-roofed residential which the intensity of light and wind directly hit the area produced less water vapor. Maximum evapotranspiration was $7 \mathrm{~mm} \mathrm{day}^{-1}$ located at position $\mathrm{x}=45$ and $\mathrm{y}=30$. Palm oil plantation in Palm oilResidential area (TM 4) although still has undeveloped canopy to cover the entire distance around the crop planting but there is a lot of grass at this site, it produced more water vapor. Based on the model, the evapotranspiration distribution at the Palm-Residential area site of PT Bio Nusantara palm oil was uneven and had value around 5-7 $\mathrm{mm}$ day $^{-1}$.

Wind speed is an important factor affecting evaporation. The wind plays a role in the movement or transfer of water vapor. If turbulence (wind speed) is high above the surface, a layer of saturated air transferred by the wind will be more numerous so that evaporation increases (Rakecha and Singh 2009; Wilson et al. 2012).

Further measurement of evapotranspiration distribution was at the location of Palm oil-Secondary forest in palm oil plantation PT. Bio Nusantara. The result of evapotranspiration measurement at the location of Palm oil-Secondary forest is shown in Figure 6. Condition of the location is the border between the palm trees TM 22 and secondary forest that contain a mixture of plants.

Minimum evapotranspiration was $5 \mathrm{~mm}^{\text {day }}{ }^{-1}$ located at $\mathrm{x}$ and $\mathrm{y}$ position $(0,75),(20,18),(40,70),(80,110)$, and $(90,20)$ respectively. Palm oil-Secondary forest plantation had similar height of altitude and similar moisture as well (>76\%), but secondary forest plants have a denser plantation density, therefore, producing less water vapor. Maximum evapotranspiration was $7.5 \mathrm{~mm}_{\text {day }}{ }^{-1}$ located at 
position $\mathrm{x}=120$ and $\mathrm{y}=80$. The location was palm oil plantation TM 22 with planting space $9 \times 9$. Moreover, there was also a short grass and soil erosion which caused more water vapor produced. This is in accordance with the opinion of Courault et al. (2003) which stated that resistance differences in transpiration, plant height, canopy closure and roots would cause differences in the magnitude of evapotranspiration.

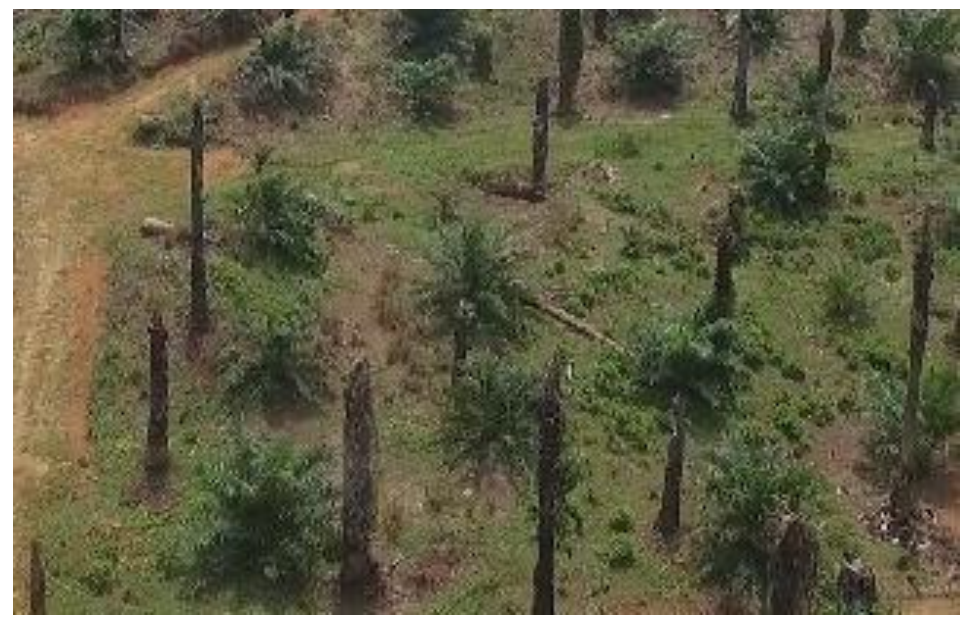

EVAPOTRANSPIRATION DISTRIBUTION MODEL

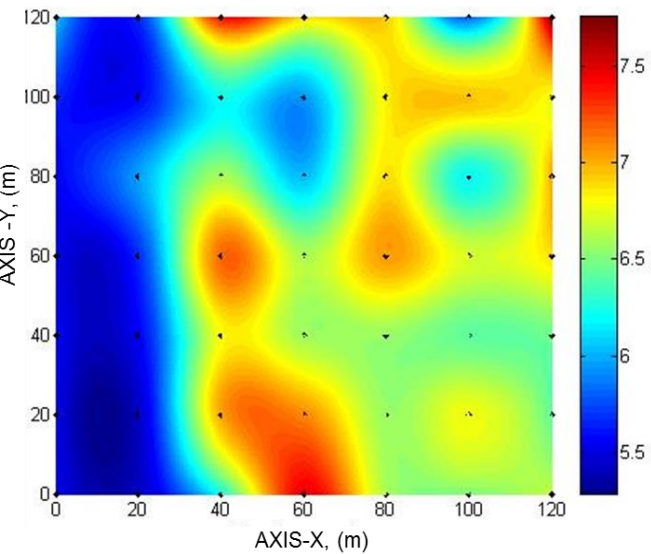

Figure 2. Evapotranspiration distribution model in plantation TM2

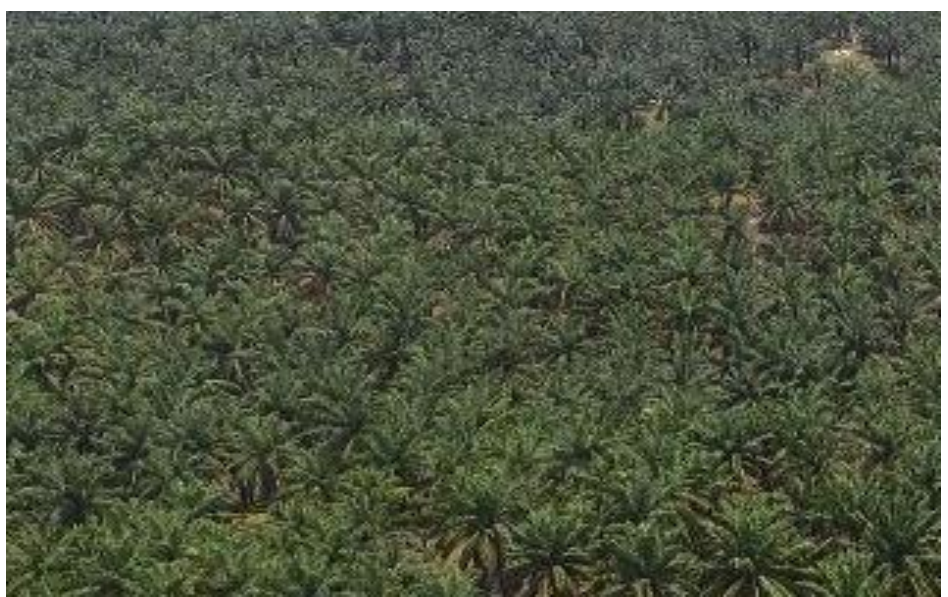

EVAPOTRANSPIRATION DISTRIBUTION MODEL

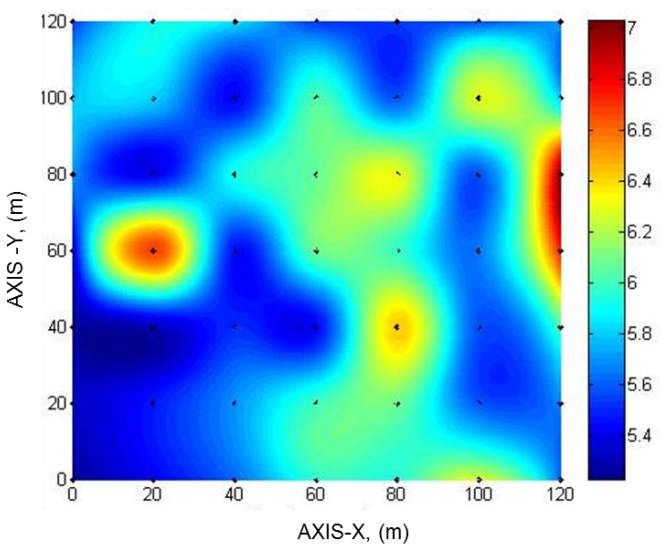

Figure 3. Evapotranspiration distribution model in plantation TM22

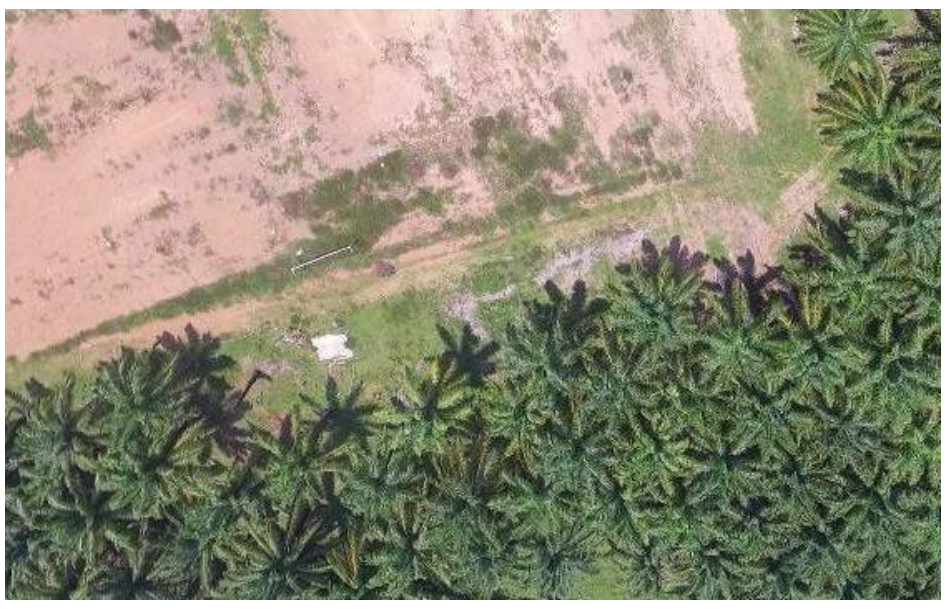

EVAPOTRANSPIRATION DISTRIBUTION MODEL

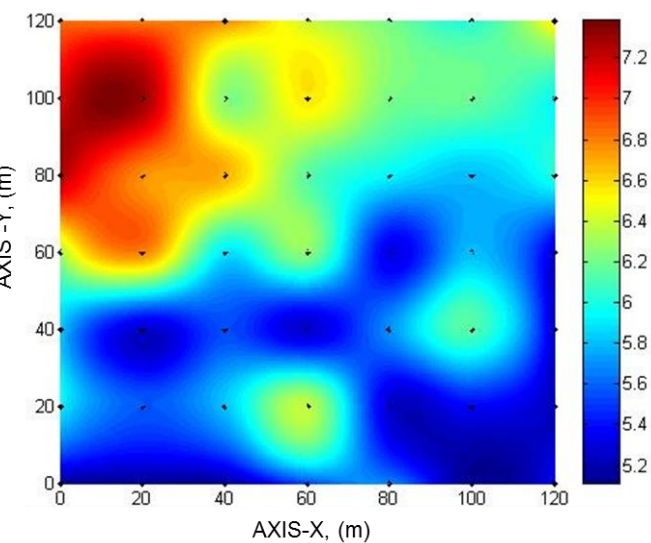

Figure 4. Evapotranspiration distribution model in palm oil-field location 

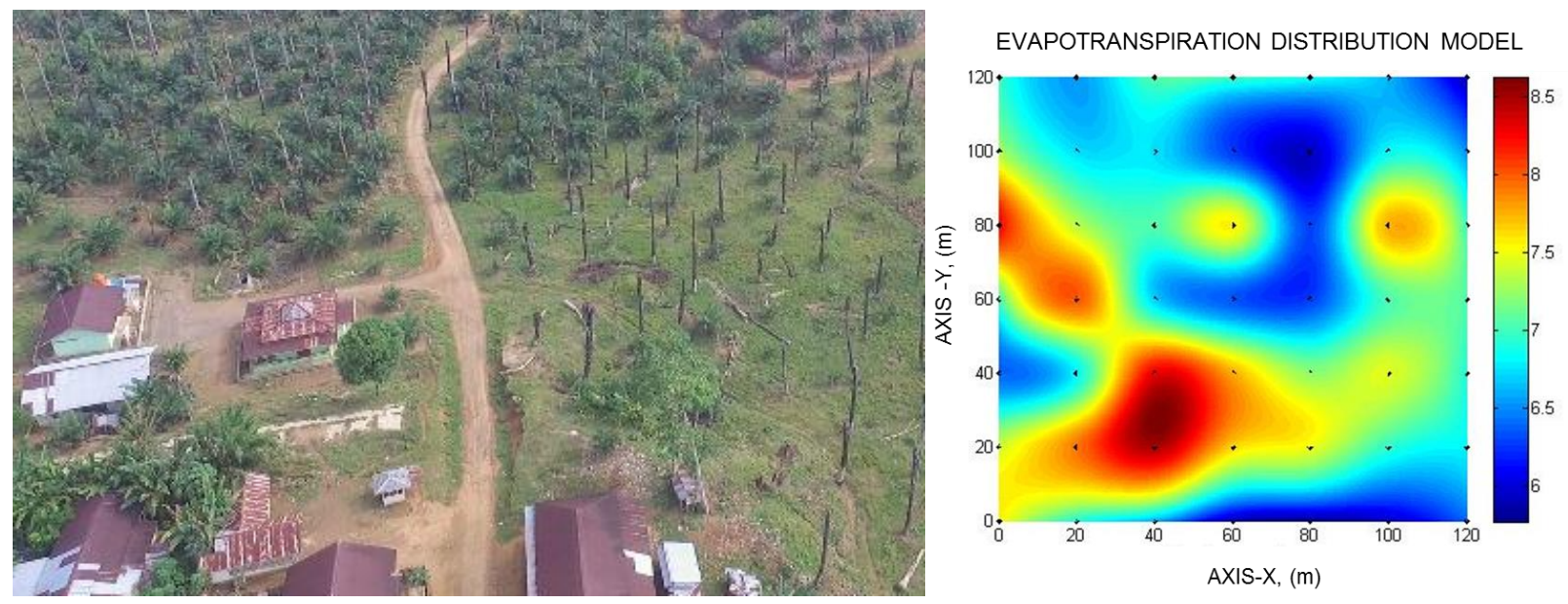

Figure 5. Evapotranspiration distribution model in Palm oil-Residential area location
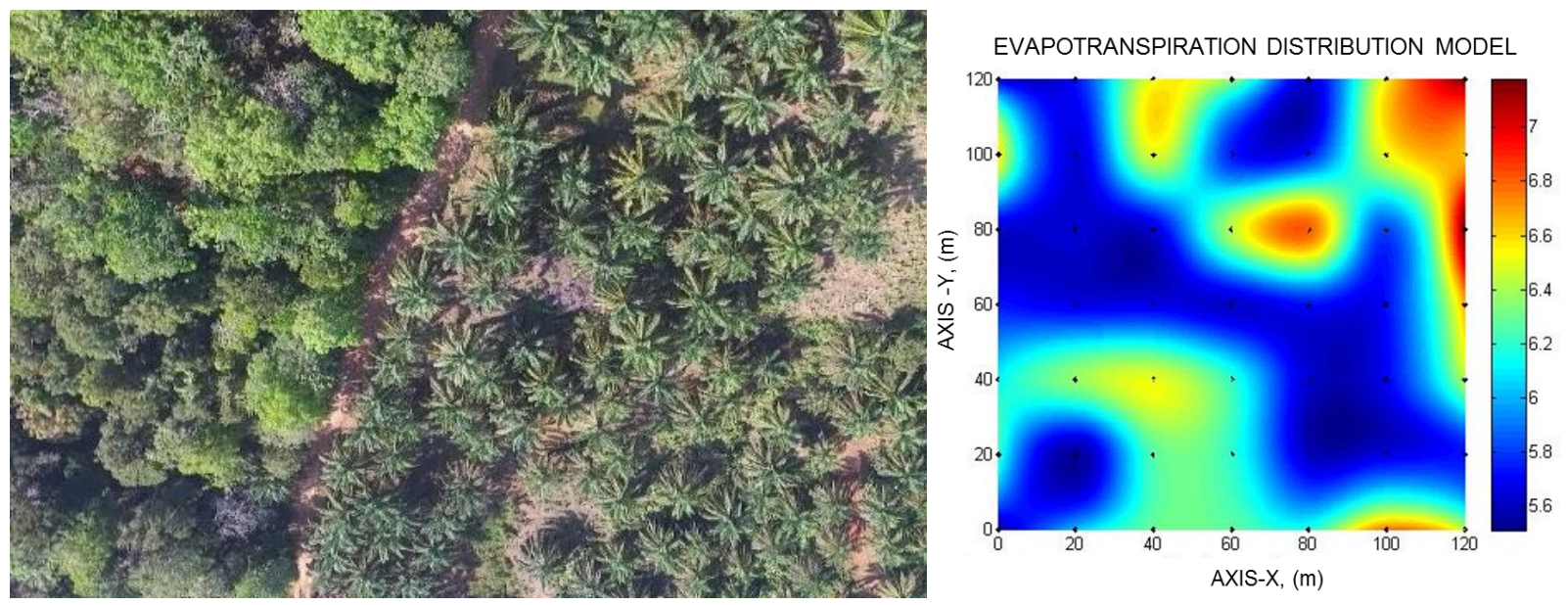

Figure 6. Evapotranspiration distribution model at Palm oil-Secondary Forest location

\section{Discussion}

At palm oil plantation TM 22 which had fully developed canopy or the entire soil area had been covered by canopy, so only transpiration occurred at this site, less water vapor was produced. This is due to the temperature condition is inversely proportional to the relative humidity. If the temperature increases, then the relative humidity decreases. Air humidity is a factor that affects evaporation because humidity describes water vapor contained by air that affects the air's capacity to absorb water vapor. If the air humidity is high, then the evaporation will decrease. These statements were confirmed when we made a comparison between area with fully developed canopy and open area like a football field. In the latter, where only has grass in the field, with low intensity of light, wind, and humidity, affected directly to high amount of evapotranspiration, therefore, more water vapor produced.

The measurement result of palm oil plantation nearby residential area showed that the area which consisted of herbaceous plants and bushes, also zinc-roofed residential with the intensity of light and wind directly hit the area, produced less water vapor. Moreover, the condition at the border area between TM 22 and the palm oil secondary forest contained mixed plantation. The measurement result showed that the palm oil secondary forest had the same height of canopy and almost had equal humidity (>76\%), but secondary forest plants had more dense plantation density which produced less water vapor.

The evapotranspiration magnitude indicates that the land in the palm oil plantation must have the ability to store water. The ability of soil to store water depends on various factors, such as the depth of the soil, soil texture, and soil organic content. The depth of the soil determines the total volume of soil in which the water can be stored. The texture of the soil determines the capacity of the field and the point of permanent wilting. The soil also can hold water in its pores. The ability to hold water is influenced by the state of the structure and texture of the soil. Water retained by soil after drainage stop can be transpired by plants or 
lost by evaporation. Plants can not use all the water stored in the soil.

The amount of available groundwater for plants is more important than the groundwater content ability. Available groundwater is showing the status of water for plants as well as related to the physiological process. Changes in groundwater content will affect the amount of available groundwater and the rate of physiological processes.

When entering the dry season, the growth and development of palm oil will be disrupted due to the water balance from palm oil plantation become unbalanced. This imbalance occurs because palm oil plantation has to water deficits that result in reduced canopy growth from palm oil plantation. Water deficit associated with the process of water loss that affects the availability of water for palm oil cultivation. The availability of ground water is affected by two dominant factors, namely precipitation in infiltration and percolation processes as water input for a system and evapotranspiration as a process of water loss from the system. It shows that evapotranspiration is not only used in the estimation of groundwater availability, it is also an indicator of plantation water requirement.

\section{ACKNOWLEDGEMENTS}

We acknowledged support from Palm oil Plantation Funds (BPDP Sawit). We would like to thank the managers of PT. Bio Nusantara, Tjutju and Nurzam for field support and cooperation, Darmono (from Indonesian Palm oil Society; MAKSI) and Arief Akbar (from BPDP Sawit reviewer) for constructive cooperation, and our field assistants for supporting us at all times during the field measurements.

\section{REFERENCES}

Allen RG, Pereira LS, Raes D, Smith M. 1998. Crop Evapotranspiration: Guidelines Computing Crop Water Requirements. FAO Irrigation and Drainage Paper 56. FAO, Rome.

Aminuddin, J. 2007. Dasar-dasar Fisika Komputasi Menggunakan MATLAB, Edisi Pertama. Gaya Media, Yogyakarta. [Indonesian]

Arshad A M, 2014. Crop Evapotranspiration and Crop Water Requirement for Palm oil in Peninsular Malaysia. J Biol Agric Healthcare 4 (16): 23-28
Bakoumé Claude, Norhazela Shahbudin, Shahrakbah Yacob, Cheah See Siang and Mohamad Nazeeb Ali Thambi. 2013. Improved Method for Estimating Soil Moisture Deficit in Palm oil (Elaeis guineensis Jacq.) Areas With Limited Climatic Data. J Agric Sci 5 (8): 57-65.

Corley RHV. 1996. Irrigation of palm oils-a review. Journal of Plantation Crops, 24 (supplement): 45-52.

Courault D, Seguin B, Olioso A. 2003. Review to estimate evapotranspiration from remote sensing data: some examples from the simplified relationship to the use of mesoscale atmospheric models. ICID Workshop on Remote Sensing of ET for Large Regions, 17 September 2003.

Dufrene E, Dubos B, Rey J, Quencez P, Suagier B. 1992. Changes in evapotranspiration from an palm oil stand (Elaeis guineensis Jacq.) exposed to seasonal soil water deficits. Oléagineux, 48 (3): 105-120.

Giancoli, Douglas C. 1998. Physics. 5th ed. Prentice Hall, Inc., New York

Harahap IY, Darmosarkoro W. 1999. Pendugaan kebutuhan air untuk pertumbuhari kelapa sawit di lapang dan aplikasinya dalam pengembangan sistem irigasi. Jumal Penelitian Kelapa Sawit 7:87104. [Indonesian]

JPS. 1991. Hydrological Procedure No. 17: Estimating Potential Evapotranspiration Using The Penman Procedure (Revised and Updated). Jabatan Pengairan dan Saliran, Kementerian Pertanian Malaysia, Putrajaya.

Kizer MA, Elliot RL. 1991. Eddy correlation system for measuring evapotranspiration. Trans Amer Soc Agric Eng 34 (2): 387-392.

Mavi HS, Tupper GJ. 1984. Agrometeorology: Principle and Applications of Climate Studies in Agriculture. Haworth Press, London.

Meijide, A, Röll, A, Fan, Y, Herbst, M, Niu, F, Tiedemann, F, 2017. Controls of water and energy fluxes in palm oil plantations: environmental variables and palm oil age. Agric For Meteorol 239: 71-85.

Mujiharjo S. 2002. Perbandingan Keeratan dan Bentuk Hubungan Evapotranspirasi Spasial (ETp) Harian dengan ETp bulanan. Jurnal Ilmu-ilmu Pertanian Indonesia 4 (1): 42-48. [Indonesian]

Penman HL. 1948. Natural evapotranspiration from open water, baresoil, and grass. Proc. R. Soc. Lond. A 193: 120-145.

Rakhecha PR, Singh VP. 2009. Applied Hydrometeorology. Springer, New Delhi, India.

Röll A, Niu F, Meijide A, Hardanto A, Hendrayanto, Knohl A, Hölscher D. 2015. Transpiration in an oil palm landscape: effects of palm age. Biogeosciences 12: 5619-5633.

Sigurdsson H, Houghton B.F. 2008. Encyclopedia of Volcanoes. Academic Press, San Diego, CA.

Sterling, S. M, Ducharne, A, and Polcher, J. (2012). The impact of global land cover change on the terrestrial water cycle. Nat Clim Ch 3: 385390.

Usman. 2004. Analisis kepekaan beberapa metode pendugaan evapotranspirasi potensial terhadap perubahan iklim. Jurnal Natur Indonesia 6 (2): 91-98. [Indonesian]

Wilson KB, Hanson PJ, Mulholland PJ, Baldocchi DD, Wullschleger SD. 2012. A comparison of methods for determining forest evapotranspiration and its components: sap-flow, soil water budget, eddy covariance and catchment water balance. Agric For Meteorol 106: $153-168$. 